\title{
Productivity, Quality, Growth and Pathological Evaluation of Some Promising Sugarcane Genotypes in Egypt
}

\author{
Mohamed A.M. Osman ${ }^{1}$ and EL-Araby S.R. Salem ${ }^{2}$ \\ ${ }^{1}$ Plant Pathology \& Entomology Dept. \\ ${ }^{2}$ Physiology \& Chemistry Dept. \\ Sugar Crops Research Inst., ARC, Giza, Egypt.
}

\begin{abstract}
This study was carried out at El-Mattana Agricultural Research Station, Luxor Governorate, Egypt(lat $25^{\circ} 17^{\prime} \mathrm{N}$, long $32^{\circ} 33^{\prime}$ and alt $76 \mathrm{~m} \mathrm{ASL}$ )during 2015/16, 2016/17 and 2017/18 harvesting seasons to study the productivity, quality, growth characters and natural infection with several diseases. Ten promising sugarcane genotypes (Saccharum spp.) constituted the studied material and check genotype (commercial genotype), namely GT 54-9 were used as control. Sugarcane genotypes were planted in a randomized complete block design with three replicates.

The results of this investigation could be summarized as follow: GT 54-9 had the highest stalk length, stalk weight, sucrose $\%$, purity $\%$ and all tested productivity characters. The highest infection with pokkah boeng, smut and mosaic diseases were observed to such genotype while, this genotype uninfected by streak disease. G 84-47 owned the highest brix $\%$, sucrose $\%$ and cane yield and had lowest DS\% for pokkah boeng disease and didn't infect by smut and two tested virus diseases. However, the highest brix\% were recorded to $\mathrm{G}$ 2006-6, which gained the lowest infection by pokkah boeng and smut, the highest infected by streak disease and uninfected by mosaic disease. The lowest mean values of stalk length, sugar yield and stalk weight were scrutinized to G 2010-26, G2011-74 and G 2011-79, respectively. These genotypes didn't infect by smut and mosaic diseases. In regard to streak disease, the highest and least infections were recorded to G 2010-26 and G 2011-79, respectively. In addition, the lowest stalk diameter and the highest number of tillers/stool were observed in case of G 2011-13 which had the highest infection by smut and uninfected by the two tested virus diseases. Also, the lowest tested qualitative traits, sugar recovery \% and yield were recorded to G2012-50. Also, G 2011-13 and G 2012-50 were the highest infected by smut and uninfected by the two tested virus diseases. G 2010-7 and G 2011-82 showed no distinct behavior for all traits. Both genotypes uninfected by smut and the two tested virus diseases. It could be concluded that, GT 54-9 genotype is suitable for regions which were contaminated only by streak disease for highest stalk weight, cane and sugar yields and G 84-47 for regions which, was contaminated by smut and the two tested virus for its highest cane yield. The traits of other genotypes were differed from season to other and had different responses to tested diseases.
\end{abstract}

Key wards: Sugarcane genotypes, Smut, Mosaic, Pokkah boeng, Streak, diseases.

\section{INTRODUCTION}

Sugarcane (Saccharum spp.) is a major sugar crop in tropical and sub-tropical countries. In Egypt, sugarcane is an important cash crop as it plays a crucial role in the economics of farmers and provides the mainstay to sugar industry in southern Egypt and also raw material to many allied industries (Mehareb et al., 2015).

Cane yield and sugar recovery are two important characters (Khan et al., 2012). Cane yield is influenced by several quality characters (Singh $e t$ al., 2003). To increase cane and sugar yield through selection for yield attributing and quality characters, the knowledge of association of various characters is important (Tahir et al., 2014). Therefore, the study of relationship of different characters with cane yield is essential, so that an appropriate and efficient selection strategy could be adopted for improvement.

Sharma (2006) stated that, the sugarcane could be affected by numerous pathogens caused by fungi; bacterial, viral and the rest are disorder of various types, i.e. physiological, mechanical and genetical). Bacteria, fungi and viruses are the major causal organisms. The losses due to these diseases may vary from place to place and depending upon the crop genotype. Therefore, the diseases could not be ignored and neglected because of their effects on the quality and/or quantity of sugarcane. Four pathogens were selected in this study because of their importance to the Egypt sugarcane industry, two fungal diseases (pokkahboeng disease caused by Fusarium moniliforme sheldon and smut caused by Sporisorium scitamineum (Piepenbring et al., 2002) and two viruses (streak disease caused by Sugarcane streak virus (SCSV) and mosaic disease caused by Sugarcane mosaic virus (SCMV) (Mehareb et al.,2018). Pokkah boeng disease recorded in all over the countries where sugarcane grown andthe pathogen spreads in windblown rain, infected cane cuttings, pupae and adults of sugarcane stem borers (Whittle and Irawan, 2000). Fusarium moniliforme var. subglutinans reduce the quality of the harvested crop mainly among genotypes with high sugar yields, the sugar production depending upon the genotype up to 40.8 $-64.5 \%$ (Duttamajumder, 2004). Under field conditions, disease symptoms were observed in four phases, namely chlorotic phases I and II, top rot, wrinkling and twisting and knife cut (Vishwakarma 
et al., 2013). Major and minoressential elements (N, $\mathrm{P}, \mathrm{K}, \mathrm{S} . \mathrm{Zn}, \mathrm{Fe}, \mathrm{Cu}$ and $\mathrm{Mg}$ ) study of the sugarcane plant affected by the pokkah boeng showed decreasing pattern in stalks and leaves of diseased plant as compared to healthy ones, this may lead to the reduction in weight of cane, length of internodes, juice percent, girth, polarity percent and total sugars in juice in infected canes of some genotypes (Vishwakarma et al., 2013).

Sugarcane smut is one of the most important diseases of the crop worldwide, which wascaused by the biotrophic fungal pathogen Sporisorium scitamineum (Piepenbringet al., 2002) (= Ustilagoscitaminea, H. Sydow \& P. Sydow) (Piepenbring et al., 2002 and Sundar et al., 2012). The disease is spread worldwide and causes considerable yield losses, and infected plants present low sucrose content and reduced number of useful culms for industrialization (Martinez et al., 2000). Reduction in yield and quality may vary considering sugarcane genotypes and was mostly dependent on the races of the pathogen, the sugarcane genotypes resistance rate and the prevailing environmental conditions (Sundaret al., 2012). Reports of estimates of economic losses have ranged from negligible to $75 \%$ (Sundaret al., 2012). The most characteristic symptom was the development of a whip-like structure from the primary meristem. This structure is composed of plant and pathogen cells and it is related to the fungal sporo genesis and spores dissemination. Plants were the most vulnerable to the pathogen attack in early sprouting stages (Tokeshi, 2005). Owing to the complexity of this patho system, plant resistance is difficult to obtain (Lemma et al., 2015). Smut is controlled by planting resistant or tolerant genotypes, removal of smutted clumps in the field, reducing the number of ratoons in susceptible genotypes and by treating seed cane with protectant fungicide (Fauconnier, 1993 and Rott et al., 2000). Modern cultivars of sugarcane were inter specific hybrids resulting from hybridization between Saccharum officinarum and S. spontaneum. These hybridswere used as source of disease resistance to smut sugarcane in breeding programs (Burner and Grisham, 1993 and Jose et al., 2016).

Streak disease caused by Sugarcane streak virus (SCSV)where, sugar cane plant infected with the streak virus shows on its leaves a pattern of straight, narrow, translucent stripes following the veins and consequently parallel to the length of the leaf. Decrease in cane yield was $11.24 \%$ in plant cane crop, $10.33 \%$ in first ratoon and $7.95 \%$ in second ratoon (Mehareb et al., 2018). Mosaic caused by Sugarcane mosaic virus (SCMV) (family: Potyviridae; genus: Potyvirus) (Grisham and Pan, 2007) . Mosaic disease was characterized by a mottled pattern on the leaves produced by contrasting light green to yellow and dark green patches. Infected plants can suffer yield losses of $20-30 \%$ or even greater in ratoons. However, if the incidence of the disease in a field is low, the overall losses were minimal. Only in highly susceptible genotypes were large patches of infected plants usually seen (Grisham 2000).

The present investigation was carried out to study productivity, quality, growth characters and natural infection or resistance of some sugarcane genotypes grown in environments in Upper Egypt to major diseases (pokkahboeng, smut, streak and mosaic) in plant cane, first and second ratoon seasons and find out the best sugarcane genotypes in cane, sugar yields and resistance to natural infection with major diseases.

\section{MATERIALS AND METHODS}

\section{Plant material and experimental conditions}

The study was carried out at El-Mattana Agricultural Research Station, Luxor Governorate, Egypt (lat $25^{\circ} 17^{\prime} \mathrm{N}$, long $32^{\circ} 33^{\prime}$ and alt $76 \mathrm{~m} \mathrm{ASL}$ ) during 2015/16, 2016/17and2017/18 harvesting seasons. Ten promising sugarcane genotypes (Saccharum spp.) namely G 84-47, G2006-6, G 2010-7, G 2010-26, G 2011-13, G 2011-74, G 201179, G 2011-82 and G 2012-50 constituted the studied material and check genotype (commercial genotype), namely GT 54-9 were used as control. Sugarcane genotypes were planted in a randomized complete block design with three replicates. Plant cane was planted in the first week of March 2015. Plot area was $49 \mathrm{~m}^{2}$ each plot contains seven rows, the length of each row seven meters, while row width was one meter and $1 \mathrm{~m}$ apart between plots. Each row ( 7 meter in length of plot) planted by 24double cutting setts contains three buds. The field was irrigated right after planting and all other agronomic practices were carried out as recommended by Sugar Crops Research Institute. Plant cane was ratooned for two consecutive years, first and second ratoons. Harvest plant cane took place 12 months after planting. The following traits were measured for sugarcane genotypes.

\section{Data were recorded for:}

\section{Growth characters:-}

At each harvesting time, 10 stalks of cane were collected at random from $2^{\text {nd }}$ and $3^{\text {ed }}$ row of each plot to determine the following traits:

1- Stalk length $(\mathrm{cm})$ was measured from soilsurface to the visible dewlap.

2- Stalk diameter $(\mathrm{cm})$ was measured at the middle part of stalks.

3- Number of tillers/toolwas calculatedas a mean number of stalks per ten stools.

4- Stalk weight $(\mathrm{kg})$ was calculated as a mean of ten stalks.

\section{Qualitative traits:-}


A sample of 20 stalks (collected at random from $2^{\text {nd }}$ and $3^{\text {ed }}$ row of each plot) was crushed and juice was analyzed to determine qualitative traits.

1- Brix\% (Total Soluble Solids percentage) was determined using Brix Hydrometer according to AOAC (1995).

2- Sucrose $\%$ of clarified juice was determined by using automated Sacharimeter according to AOAC (1995).

3- Purity \% was calculated according to the following formula:

Purity percentage $=\frac{\text { Sucrose percentage }}{\text { Brix percentage }} \times 100$

3. Productivity characters:-

1- Sugar recovery \% was calculated according to the following formula described by Yadav\& Sharma (1980).

Sugar recovery \% $=[$ Sucrose \% $0.4($ Brix \% -

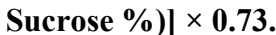

2- Cane yield (ton/fed) was determined from the weight of $4^{\text {th }}, 5^{\text {th }}$ and $6^{\text {th }}$ rows of each plot converted into ton per fed.
3- Sugar yield (tons/fed) was calculated according to the following equation:

Sugar yield $($ ton $/$ fed) $=$ Cane yield $($ ton $/$ fed $) \times$ Sugar recovery $\%$.

4. Determination of the infected sugarcane promising genotypes with some diseases:

1- Pokkahboeng disease:

a- Infected plants percentage:

Infected plants percentage with disease previously mentioned above were calculated according to the following equation:

b- Infected plants $\%=\frac{\text { Number of naturally infected plants }}{\text { Number of total grown plants }} \times \mathbf{1 0 0}$

Disease severity percentage (DS \%) of plants:

Severity of the disease was made by comparing the infected plant tissues that produced pokkahboeng symptoms to that of healthy plant tissues. The symptoms were scored with disease scales 0 to 4 (Photo, 1) as described by Ramirez and Nass (2005).

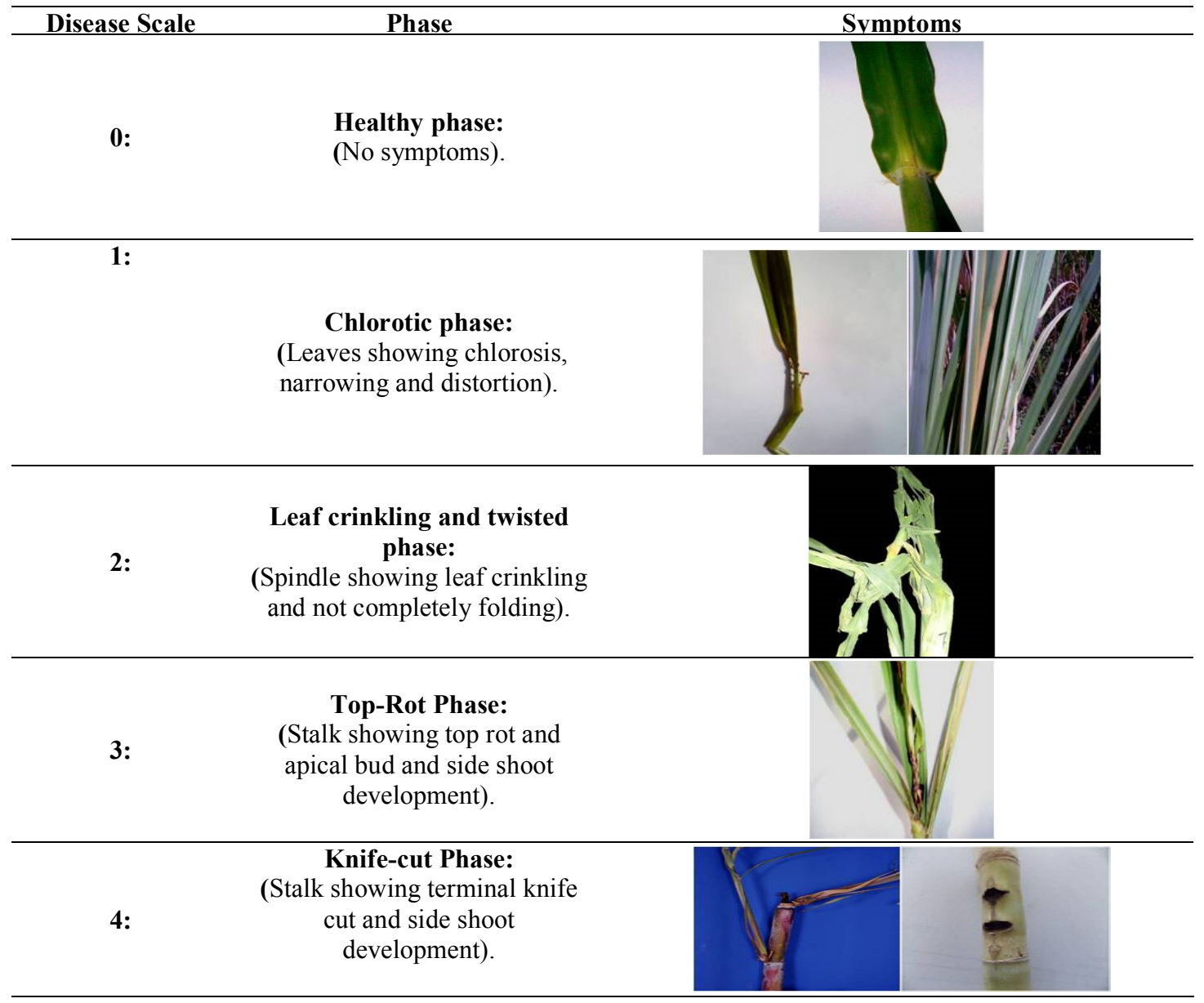

Photo 1: Disease scale and severity index used in pokkahboeng disease. 
The disease severity index (DSI \%) was calculated based on the disease scaleat 12 months from planting, for each replicate.

A disease severity (DS \%) was calculated due to the following formula:

$$
\text { DS\% }=\frac{\Sigma(A \times n)}{\Sigma B \times \text { Maximum possiblescore }(4)} \times 100
$$

Where:

$\mathrm{A}=$ disease scale $(0,1,2,3$ or 4$)$.

$\mathrm{n}=$ number of stalks for each disease scale.

$\mathrm{B}=$ total number of stalks.

2- Smut disease (photo, 2):

Number of smut-affected stools was counted in plant cane season at 45 days after planting until 90 days age, while in the first ratoon and second ratoon seasons number of smut-affected stools was counted at 45 days after harvested until 90 days age. The incidence of the disease was computed using formula of Amrote (2014):

\section{Smut disease incidence $(\%)=$ Number of naturally infecteds tools Total Number of stools}

\section{3- Streakdisease (Photo,3). \\ 4- Mosaic disease(Photo, 4).}

Infected plants percentage with diseases were calculated as mentioned above in pokkahboeng disease.

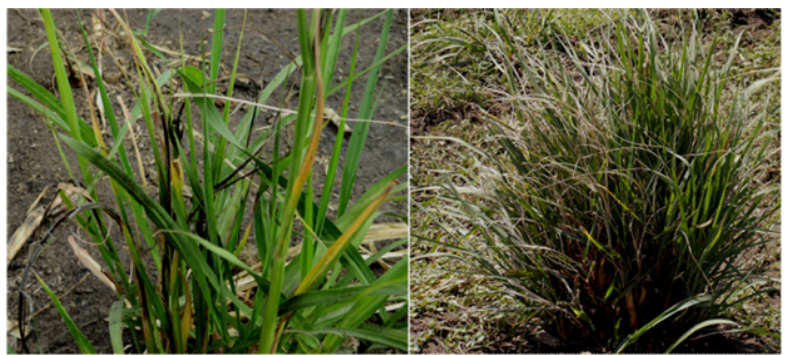

Photo 2: Symptoms of smut disease.

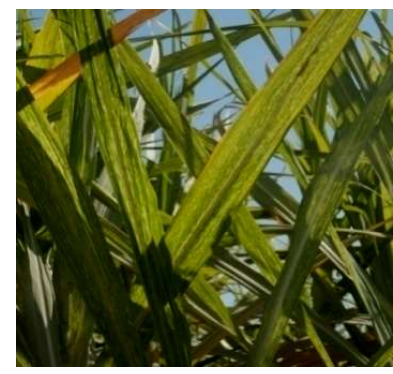

Photo 3: Symptoms of streak disease.

\section{Statistical analysis}

To determine the significant differences among treatments mean values at 0.05 probability level, all data were subjected to two-way analysis of variance (ANOVA) followed by the least significant differences (L.S.D) at the $0.05 \leq$ level which were determined according to computer program (COSTAT software, 1988) to compare the average numbers of the inspected insect at different intervals (Steel and Torrie, 1981).

\section{RESULTS AND DISCUSSION}

\section{Growth characters:-}

Data in Table (1) revealed that there were significant differences among tested sugarcane genotypes in stalk length and diameter in plant cane, during the first and second ratoon crops. Where, the highest values of stalk length were recorded by GT 54-9, G 84-47 for the three tested seasons, and by $\mathrm{G}$ 2011-79 in plant cane and the $2^{\text {nd }}$ ratoon and G 2011-

\section{Photo 4: Symptoms of mosaic disease.}

13 in the $1^{\text {st }}$ and $2^{\text {nd }}$ ratoon crops. On the other hand, the least values of stalk length were produced by $\mathrm{G}$ 2006-6 and G 2010-26 genotypes in plant cane with no significant difference between them, and the $2^{\text {nd }}$ genotype in $1^{\text {st }}$ and $2^{\text {nd }}$ ratoon crops.

Thus, the least values of stalk diameter were recorded in G 84-47, G 2011-13, G 2011-79 and G 2012-50 genotypes in plant cane with no significant differences among them, G 84-47, G 2011-13, G 2011-74 and G 2012-50 genotypes in first ratoon and $\mathrm{G}$ 2011-13 genotype in second ratoon crops as shown in Table (1). These differences among genotypes may be due to the genetic makeup of them. These results are in accordance with those obtained by Mehareb et al. (2015 \& 2017) and Mehareb and Galal (2017) and Abo Elenen et al. (2018), who found that the studied genotypes significantly differed in stalk diameter and stalk length. 
Table 1: Differences among tested genotypes in stalk length anddiameter in the tested seasons 2015/16 (plant cane), 2016/17 (first ratoon) and 2017/18 (second ratoon)

\begin{tabular}{lcccccc}
\hline \multirow{2}{*}{ Genotypes } & \multicolumn{3}{c}{ Stalk length (cm) } & \multicolumn{3}{c}{ Stalk diameter (cm) } \\
\cline { 2 - 7 } & Plant cane & $\mathbf{1}^{\text {st }}$ ratoon & $\mathbf{2}^{\text {nd }}$ ratoon & Plant cane & $\mathbf{1}^{\text {st }}$ ratoon & $\mathbf{2}^{\text {nd }}$ ratoon \\
\hline GT 54-9 & $255.3 \mathrm{a}$ & $295.5 \mathrm{a}$ & $274.0 \mathrm{a}$ & $2.80 \mathrm{~b}$ & $2.55 \mathrm{~b}$ & $2.71 \mathrm{a}$ \\
\hline G 84-47 & $261.8 \mathrm{a}$ & $287.5 \mathrm{ab}$ & $236.5 \mathrm{c}$ & $2.35 \mathrm{~cd}$ & $2.16 \mathrm{de}$ & $2.46 \mathrm{~b}$ \\
\hline G 2006-6 & $199.0 \mathrm{~d}$ & $236.5 \mathrm{~d}$ & $240.0 \mathrm{bc}$ & $3.15 \mathrm{a}$ & $2.56 \mathrm{~b}$ & $2.39 \mathrm{~b}$ \\
\hline G 2010-7 & $233.0 \mathrm{bc}$ & $256.5 \mathrm{c}$ & $255.5 \mathrm{~b}$ & $2.77 \mathrm{~b}$ & $2.40 \mathrm{bc}$ & $2.25 \mathrm{bc}$ \\
\hline G 2010-26 & $184.5 \mathrm{~d}$ & $208.5 \mathrm{e}$ & $218.5 \mathrm{~d}$ & $2.86 \mathrm{~b}$ & $2.83 \mathrm{a}$ & $2.80 \mathrm{a}$ \\
\hline G 2011-13 & $224.0 \mathrm{bc}$ & $291.5 \mathrm{ab}$ & $278.0 \mathrm{a}$ & $2.19 \mathrm{~d}$ & $1.72 \mathrm{e}$ & $1.61 \mathrm{e}$ \\
\hline G 2011-74 & $232.0 \mathrm{bc}$ & $275.5 \mathrm{~b}$ & $239.2 \mathrm{bc}$ & $2.47 \mathrm{c}$ & $1.92 \mathrm{e}$ & $2.20 \mathrm{c}$ \\
\hline G 2011-79 & $255.0 \mathrm{a}$ & $259.5 \mathrm{c}$ & $285.8 \mathrm{a}$ & $2.30 \mathrm{~cd}$ & $2.32 \mathrm{~cd}$ & $2.37 \mathrm{~b}$ \\
\hline G 2011-82 & $237.0 \mathrm{~b}$ & $271.0 \mathrm{~b}$ & $272.5 \mathrm{a}$ & $2.39 \mathrm{c}$ & $2.33 \mathrm{~cd}$ & $2.13 \mathrm{c}$ \\
\hline G 2012-50 & $222.0 \mathrm{c}$ & $254.0 \mathrm{~cd}$ & $248.0 \mathrm{bc}$ & $2.22 \mathrm{~d}$ & $2.01 \mathrm{e}$ & $1.85 \mathrm{~d}$ \\
\hline M 2010
\end{tabular}

Means followed by same letter within each column are not significantly different at 0.05 level of probability

Data in Table (2) showed that there were significant differences among tested genotypes in the number of tillers/stool and stalk weight in plant cane, first and second ratoon crops. Where, the highest mean values of number of tillers/stool were scored by G 2011-13 and G 2011-79 genotypes in plant cane with no significant difference between them,G2011-13, G 2011-79, G 2011-82 and G 2012-50 genotypes in first ratoonandGT54-9, G 8447, G 2010-26, G 2011-13, G 2011-74, G 2011-79, $\mathrm{G}$ 2012-50 andG2011-82 genotypes in second ratoon crop.

Accordingly, the highest mean values of stalk weight $(\mathrm{kg})$ were recorded by GT 54-9, G 84-47 and G 2006-6 genotypes in plant cane with no significant differences among them, GT 54-9, G 2010-7 and G 2010-26 genotypes in first ratoon and GT 54-9, G 2006-6, G 2010-7 and G 2010-26 genotypes in second ratoon crop. On the other hand, the least mean values of tillers number/stool were scored by GT 54-9, G 84-47, G 2006-6, G 2010-7, G 2010-26, G 2011-74 andG2011-82 genotypes in plant cane with no significant differences among them, GT 54-9, G 2010-7, G 2010-26 andG2011-74 genotypes in first ratoon and G 2006-6 andG2010-7 genotypes in second ratoon crop. Thus, the least mean values of stalk weight were produced byG2011-74 andG2012-50 genotypes in plant cane with no significant difference between them,G20066,G 2011-79, G 2011-82 and G 2012-50 genotypes in first ratoon and G84-47, G 2011-13, G 2011-74, G 2011-79, G 2011-82 andG 2012-50 genotypes in second ratoon crop. The dissimilarities among genotypes were also reported by Mehareb et al. (2015), Mehareb and Galal (2017) and Abo Elenen et al. (2018).

2. Qualitative traits:-

Data recorded in Table (3) indicated that, the examined sugar cane genotypes significantly differed in brix \%, sucrose and purity percentages during plant cane, first and second ratoon crops. Where, the highest brix percentage values were recorded by G 2011-79, G 2011-79,G 84-47 andG 2006-6genotypesin plant cane with no significant differences among them,G84-47andG 2006-6genotypesin the first ratoonand $G$ 84-47,G 2011-82, G 2006-6, G 2010-26, G 2011-13, G 201179 , GT 54-9genotypes in the second ratoon crop.

Inconsequence, the highest values of sucrose percentage were produced from GT 54-9, G 84-47, G 2006-6, G 2010-26 andG2011-79 in plant cane with no significant differences among them, moreover, G 84-47, GT54-9 and G 2006-6 in first ratoon and G2011-79, GT54-9, G 84-47 and G 2011-82 in the second ratoon crop.

While, the highest purity percentage mean values were scored by GT 54-9,G84-47, G 2006-6, G2010-7, G 2010-26 and G 2011-13 in plant cane with no significant differences among them, furthermore, GT 54-9, G 84-47 and G 2006-6 in the first ratoon and $G$ 2011-79 andGT 54-9 in the second ratoon crop.Otherwise, the least purity percentage values were produced by G 2012-50, G2011-13 with no significant difference between them, also, G 2010-7 in first and G 2012-50 and G 2010-7 in second ratoon crops. Similarly, the least values of purity percentage were recorded by G 211 74, G 201179, G 2011-82 andG 2012-50 in plant cane with no significant differences among them, moreover, G 211-74, G 201179, G 2011-82, G 2012-50, G 2-11-13, G 2010-26 andG 2010-7 in first ratoon and G 84-47, G 2006-6, G 2010-7, G 2010-26 and G 2012-50 in second ratoon crops. On the other hand, the least brix percentage and sucrose percentage mean values were recorded by G 2012 50 genotypes in plant cane, first and second ratoon crops and G 2011-79 in first and second ratoon crops. These results may be due to the genetic makeup of those genotypes. Differences among genotypes were also reported by Meharebet al. (2015), Mehareb and Galal (2017) and Abo Elenen et al. (2018). 
Table 2: Differences among tested genotypes in numberof tillers/stool and stalk weight in the tested seasons 2015/16 (plant cane) 2016/17 (first ratoon) and 2017/18 (second ratoon)

\begin{tabular}{lcccccc}
\hline \multirow{2}{*}{ Genotypes } & \multicolumn{3}{c}{ Number of tillers/stool } & \multicolumn{3}{c}{ Stalk weight (kg) } \\
\cline { 2 - 7 } & Plant cane & $\mathbf{1}^{\text {st }}$ ratoon & $\mathbf{2}^{\text {nd }}$ ratoon & Plant cane & $\mathbf{1}^{\text {st }}$ ratoon & $\mathbf{2}^{\text {nd }}$ ratoon \\
\hline GT 54-9 & $3.54 \mathrm{c}$ & $4.47 \mathrm{bc}$ & $2.87 \mathrm{ab}$ & $1.35 \mathrm{ab}$ & $1.18 \mathrm{ab}$ & $0.67 \mathrm{ab}$ \\
\hline G 84-47 & $3.04 \mathrm{c}$ & $5.14 \mathrm{~b}$ & $3.66 \mathrm{a}$ & $1.45 \mathrm{a}$ & $0.91 \mathrm{~b}$ & $0.49 \mathrm{~b}$ \\
\hline G 2006-6 & $3.04 \mathrm{c}$ & $4.89 \mathrm{~b}$ & $2.36 \mathrm{~b}$ & $1.32 \mathrm{ab}$ & $0.85 \mathrm{bc}$ & $0.61 \mathrm{ab}$ \\
\hline G 2010-7 & $3.64 \mathrm{bc}$ & $4.30 \mathrm{bc}$ & $2.53 \mathrm{~b}$ & $1.04 \mathrm{bc}$ & $1.27 \mathrm{a}$ & $0.69 \mathrm{a}$ \\
\hline G 2010-26 & $3.13 \mathrm{c}$ & $4.47 \mathrm{bc}$ & $2.70 \mathrm{ab}$ & $1.21 \mathrm{~b}$ & $1.07 \mathrm{ab}$ & $0.63 \mathrm{ab}$ \\
\hline G 2011-13 & $4.55 \mathrm{ab}$ & $5.47 \mathrm{ab}$ & $2.97 \mathrm{ab}$ & $0.64 \mathrm{~d}$ & $0.97 \mathrm{~b}$ & $0.55 \mathrm{~b}$ \\
\hline G 2011-74 & $2.87 \mathrm{c}$ & $3.96 \mathrm{c}$ & $2.97 \mathrm{ab}$ & $0.95 \mathrm{c}$ & $0.90 \mathrm{~b}$ & $0.46 \mathrm{~b}$ \\
\hline G 2011-79 & $5.06 \mathrm{a}$ & $5.47 \mathrm{ab}$ & $3.66 \mathrm{a}$ & $0.69 \mathrm{~d}$ & $0.84 \mathrm{bc}$ & $0.45 \mathrm{~b}$ \\
\hline G 2011-82 & $3.20 \mathrm{c}$ & $6.41 \mathrm{a}$ & $3.30 \mathrm{ab}$ & $1.19 \mathrm{~b}$ & $0.74 \mathrm{bc}$ & $0.52 \mathrm{~b}$ \\
\hline G 2012-50 & $4.22 \mathrm{~b}$ & $6.14 \mathrm{ab}$ & $2.96 \mathrm{ab}$ & $0.88 \mathrm{c}$ & $0.65 \mathrm{c}$ & $0.54 \mathrm{~b}$ \\
\hline
\end{tabular}

Means followed by same letter within each column are not significantly different at 0.05 level of probability

Table 3: Differences among tested genotypes in some qualitative characters (brix \%, sucrose\% and purity \%) in the tested seasons 2015/16 (plant cane) 2016/17 (first ratoon) and 2017/18 (second ratoon)

\begin{tabular}{|c|c|c|c|c|c|c|c|c|c|}
\hline \multirow[b]{2}{*}{ Genotypes } & \multicolumn{3}{|c|}{ Brix\% } & \multicolumn{3}{|c|}{ Sucrose\% } & \multicolumn{3}{|c|}{ Purity\% } \\
\hline & Plant cane & $1^{\text {st }}$ ratoon & $2^{\text {nd }}$ ratoon & Plant cane & $1^{\text {st }}$ ratoon & $2^{\text {nd }}$ ratoon & Plant cane & $1^{\text {st }}$ ratoon & $2^{\text {nd }}$ ratoon \\
\hline GT 54-9 & $20.77 \mathrm{~b}$ & $19.46 \mathrm{c}$ & $20.45 \mathrm{a}$ & $17.11 \mathrm{a}$ & $16.80 \mathrm{a}$ & $17.04 \mathrm{a}$ & $82.36 \mathrm{a}$ & $86.33 \mathrm{a}$ & $83.37 \mathrm{a}$ \\
\hline G 2006-6 & $20.92 \mathrm{ab}$ & $20.60 \mathrm{a}$ & $20.53 \mathrm{a}$ & $16.71 \mathrm{ab}$ & $17.27 \mathrm{a}$ & $15.67 \mathrm{~b}$ & $79.84 \mathrm{a}$ & $83.85 \mathrm{a}$ & $76.37 \mathrm{c}$ \\
\hline G 2010-7 & $19.55 \mathrm{bc}$ & $18.75 \mathrm{~d}$ & $18.94 \mathrm{~b}$ & $15.63 \mathrm{bc}$ & $14.03 \mathrm{~b}$ & $14.39 \mathrm{~cd}$ & $79.97 \mathrm{a}$ & $74.80 \mathrm{~b}$ & $75.99 \mathrm{c}$ \\
\hline G 2011-13 & $19.68 \mathrm{bc}$ & $20.17 \mathrm{~b}$ & $19.65 \mathrm{ab}$ & $15.01 \mathrm{c}$ & $14.31 \mathrm{~b}$ & $15.64 \mathrm{~b}$ & $76.19 \mathrm{a}$ & $70.92 \mathrm{~b}$ & $79.61 \mathrm{~b}$ \\
\hline G 2011-74 & $19.09 \mathrm{c}$ & $17.86 \mathrm{f}$ & $19.33 \mathrm{~b}$ & $13.63 \mathrm{c}$ & $13.90 \mathrm{~b}$ & $15.55 \mathrm{~b}$ & $71.45 \mathrm{~b}$ & $77.80 \mathrm{~b}$ & $80.42 \mathrm{~b}$ \\
\hline G 2011-79 & $21.66 \mathrm{a}$ & $16.31 \mathrm{~g}$ & $19.97 \mathrm{ab}$ & $16.09 \mathrm{abc}$ & $12.87 \mathrm{bc}$ & $17.18 \mathrm{a}$ & $74.30 \mathrm{~b}$ & $78.91 \mathrm{~b}$ & $86.00 \mathrm{a}$ \\
\hline G 2011-82 & $20.49 \mathrm{bc}$ & $19.26 \mathrm{c}$ & $20.18 \mathrm{ab}$ & $14.50 \mathrm{c}$ & $14.31 \mathrm{~b}$ & $16.53 \mathrm{ab}$ & $70.81 \mathrm{~b}$ & $74.30 \mathrm{~b}$ & $81.91 \mathrm{~b}$ \\
\hline G 2012-50 & $17.90 \mathrm{~d}$ & $15.7 \mathrm{oh}$ & $17.78 \mathrm{c}$ & $12.05 \mathrm{~d}$ & $11.21 \mathrm{c}$ & $13.77 \mathrm{~d}$ & $67.42 \mathrm{~b}$ & $71.40 \mathrm{~b}$ & $77.44 \mathrm{c}$ \\
\hline
\end{tabular}

Means followed by same letter within each column are not significantly different at 0.05 level of probability

\section{Productivity characters:-}

Data in Table (4) confirmed that there were significant differences among tested genotypes in sugar recovery percentage, cane and sugar yields during plant cane, first and second ratoon crops. There were no significant differences among the following genotypes GT 54-9, G 84-47, G 2006-6, G 2010-7, G 2010-26 and G 2011-79 which gave the highest sugar recovery percentage values in plant cane, as well, G 84-47, GT 54-9, G 2006-6, G 2010-26, G 2011-74 and G 2011-82 genotypes in first ratoon and G 2011-79, GT 54-9, G 2011-79 and G 2011-82 genotypes in second ratoon crop. On the other hand, the least mean values of sugar recovery percentage were recorded by G 2011-74 and G 2012-50 genotypes in plant cane with no significant differences between them, in addition, G 2011-13, G 2011-79 and G 2012-50 genotypes in first ratoon crop and G 84-47, G 2006-6, G 2010-7, G 2010-26, G 2011-13, G 2011-74 and G 2012-50 genotypes in second ratoon crop.

The highest cane yield (ton/fed) mean values were recorded by GT 45-9 and G 84-47 genotypes in plant cane with no significant differences between them, in consequence, GT 54-9, G 84-47, G 2010-7, G 2010-26, G 2011-13, G 2011-79 and G 2011-82 genotypes in first ratoon and GT 54-9, G 84-47 and G 2010-7 genotypes in second ratoon crops. On the other hand, studying cane yield (ton/fed) character showed that there were no significant differences between G 2011-13and G 2011-74 genotypes during the three tested seasons, which, gained the least values in plant cane, moreover, G 2006-6, G 2011-74 and G 2012-50 genotypes in first ratoon and G 2011-74, G 2011-79, G 2011-82, G 2012-50 and G 2006-6 genotypes in second ratoon crop.

As a result, the highest mean values of sugar yield (ton/fed) were scored by GT 54-9, G 84-47, G 2006-6, G 2010-7, G 2010-26 and G 2011-13 genotypes in plant cane with no significant differences among them, some place, GT 54-9 and G 84-47 genotypes in first ratoon and GT 54-9 genotype in second ratoon crop as shown in Table (4). 
Table 4: Differences among tested genotypes in productivity characters (sugar recovery\%, cane yield ton/fed and sugar yield ton/fed) in the tested seasons 2015/16 (plant cane) 2016/17 (first ratoon) and $2017 / 18$ (second ratoon)

\begin{tabular}{|c|c|c|c|c|c|c|c|c|c|}
\hline Genotypes & \multicolumn{3}{|c|}{ Sugar recovery\% } & \multicolumn{3}{|c|}{ Cane yield (ton/fed) } & \multicolumn{3}{|c|}{ Sugar yield (ton/fed) } \\
\hline GT 54-9 & $11.42 \mathrm{a}$ & $11.49 \mathrm{a}$ & $11.45 \mathrm{ab}$ & $57.91 \mathrm{a}$ & $63.57 \mathrm{a}$ & $45.03 \mathrm{a}$ & $6.61 \mathrm{a}$ & $7.30 \mathrm{a}$ & $5.15 \mathrm{a}$ \\
\hline G 2006-6 & $10.96 \mathrm{ab}$ & $11.64 \mathrm{a}$ & $10.02 \mathrm{~b}$ & $48.43 \mathrm{~b}$ & $51.03 \mathrm{~b}$ & $38.96 \mathrm{bc}$ & $5.31 \mathrm{a}$ & $5.93 \mathrm{~b}$ & $3.91 \mathrm{~cd}$ \\
\hline G 2010-7 & $10.26 \mathrm{ab}$ & $8.86 \mathrm{~b}$ & $9.18 \mathrm{~b}$ & $46.17 \mathrm{~b}$ & $65.98 \mathrm{a}$ & $42.91 \mathrm{ab}$ & $4.74 \mathrm{ab}$ & $5.85 \mathrm{~b}$ & $3.94 \mathrm{~cd}$ \\
\hline G 2010-26 & $10.58 \mathrm{ab}$ & $9.13 \mathrm{ab}$ & $9.76 \mathrm{~b}$ & $45.94 \mathrm{~b}$ & $57.84 \mathrm{ab}$ & $40.97 \mathrm{~b}$ & $4.86 \mathrm{ab}$ & $5.28 \mathrm{bc}$ & $4.00 \mathrm{~cd}$ \\
\hline G 2011-74 & $8.36 \mathrm{bc}$ & $8.99 \mathrm{ab}$ & $10.24 \mathrm{~b}$ & $33.00 \mathrm{c}$ & $43.20 \mathrm{~b}$ & $35.16 \mathrm{c}$ & $2.76 \mathrm{c}$ & $3.88 \mathrm{~cd}$ & $3.60 \mathrm{~d}$ \\
\hline G 2011-79 & $10.12 \mathrm{ab}$ & $8.39 \mathrm{bc}$ & $11.72 \mathrm{a}$ & $42.76 \mathrm{~b}$ & $56.25 \mathrm{ab}$ & $39.25 b c$ & $4.33 \mathrm{~b}$ & $4.75 \mathrm{c}$ & $4.60 \mathrm{~b}$ \\
\hline G 2011-82 & $8.84 \mathrm{~b}$ & $9.00 \mathrm{ab}$ & $11.00 \mathrm{ab}$ & $45.54 \mathrm{~b}$ & $58.03 \mathrm{ab}$ & $37.27 \mathrm{c}$ & $4.05 \mathrm{bc}$ & $5.23 \mathrm{bc}$ & $4.10 \mathrm{c}$ \\
\hline G 2012-50 & $7.09 \mathrm{c}$ & $6.87 \mathrm{c}$ & $8.88 \mathrm{~b}$ & $45.08 \mathrm{~b}$ & $48.93 \mathrm{~b}$ & $37.61 \mathrm{c}$ & $3.21 \mathrm{c}$ & $3.36 \mathrm{~d}$ & $3.34 \mathrm{~d}$ \\
\hline
\end{tabular}

Means followed by same letter within each column are not significantly different at 0.05 level of probability

Thus, the least mean values of sugar yield (ton/fed) were scored by G 2011-13, G 2011-74, G 2011-82 and G2012-50 genotypes in plant cane without significant differences among them,G2011-74 and G2012-50 in first ratoon and G2006-6, G 2010-7, G 2010-26, G 2011-74 and G 2012-50 in second ratoon crop as shown in Table (4). These results may be due to the genetic composition of those genotypes. The same differences among genotypes were also reported by Mehareb et al. (2015\& 2017); Mehareb and Galal (2017) and Abo Elenen et al. (2018)

The increase in cane and sugar yields in first ratoon than plant cane or second ratoon yields may be due to the increase in number of tillers/stool in first ratoon compared with that of plant cane or with that of second ratoon.

5. Susceptibility of certain sugarcane promising genotypes to infection with pokkahboeng, smut, streak and mosaic diseases:

Susceptibility of ten sugarcane promising genotypes to infection with the major pathogens in Upper Egypt pokkah boeng, smut, streak and mosaic diseases were tested under field and natural infection in plant cane $(2015 / 2016)$, first ratoon (2016/2017) and second ratoon (2017/2018) seasons.

\subsection{Fungal diseases:}

5.1.1. Susceptibility of sugarcane promising genotypes to infect and disease severity (DS\%) with Pokkah boeng disease under natural conditions:

Data in Table (5) indicated that, for infection $\%$ the high susceptibility percentage $(8.33 \%)$ to pokkah boeng disease in plant cane season, was recorded by G 2011-82 and the low susceptibility percentage (1.67) was recorded by $G$ 2006-6, G 2011-74. On the other hand, in the first ratoon season, the high susceptibility percentage to disease were recorded by GT 54-9 (16.67\%), while the low susceptibility percentage was recorded by G 2006-6 (5.00\%), G 2010-7 (5.00\%), G 2010-26 (3.33\%) and
G 2011-74 (3.33\%). In addition, in the second ratoon season, the high susceptibility percentages were recorded by GT 54-9 (25.00\%) and G 2011-13 $(21.67 \%)$ and the low infected percentage were recorded by $G$ 2010-26 (5.00\%) and $G$ 2011-74 $(5.00 \%)$.

However, the tested promising genotypes were significantly differed in severity infection with pokkah boeng disease in the three tested seasons. Regarding to DS\%, in plant cane season the high percentage $(2.08 \%)$ of DS with pokkah boeng disease were scored by GT 54-9 and the low DS percentage $(0.42 \%)$ were recorded by G $84-47$ and $\mathrm{G}$ 2010-26. On the other hand, in the first ratoon season, the high DS percentage with such disease were recorded by G 2011-82 (5.42\%), GT 54-9 $(5.00 \%)$, while the low DS percentage were recorded by all genotypes tested except GT 54-9 and G 2011-82 genotypes mentioned above, also in the second ratoon season, GT 54-9 genotype showed the high DS percentage $(12.92 \%)$ and the low DS percentage $(1.25 \%)$ were recorded by $\mathrm{G} 47-84, \mathrm{G}$ 2006-6 and G 2010-26 genotypes.

Variation in susceptibility among sugarcane promising genotypes to infection with pokkah boeng disease was reported by Cuenya et al. (2011) and Osman et al. (2014). These differences may be due to certain physiological aspects and certain compounds that have an antifungal effect on the pathogen such as phenol compounds and enzymes related plant defense. The leaves of resistant sugarcane genotypes to infection with pokkah boeng disease contained more phenolic compounds than those of susceptible ones (Agrios, 2005, Osman et al., 2014 and Mehareb et al., 2018).The resistant sugarcane genotypes may be producing self-defense mechanisms such as biochemical and physiological defense mechanisms that kill the pathogen caused pokkahboeng disease or prevent its spread through the plant (Agrios, 2005 and Mehareb et al., 2018). 
Table 5: Susceptibility of certain sugarcane promising genotypes to infection percentage and disease severity percentage with pokkahboeng disease and infection with smut disease under natural conditions in the tested seasons 2015/16 (plant cane) 2016/17 (firstratoon) and 2017/18 (second ratoon)

\begin{tabular}{|c|c|c|c|c|c|c|c|c|c|}
\hline \multirow{3}{*}{ Genotypes } & \multicolumn{6}{|c|}{ Pokkahboeng disease } & \multirow{2}{*}{\multicolumn{3}{|c|}{$\begin{array}{c}\text { Smut disease } \\
\text { Infected \% }\end{array}$}} \\
\hline & \multicolumn{3}{|c|}{ Infected \% } & \multicolumn{3}{|c|}{ Disease severity \% } & & & \\
\hline & $\begin{array}{l}\text { Plant } \\
\text { cane }\end{array}$ & $\begin{array}{c}1 \text { st } \\
\text { ratoon }\end{array}$ & $\begin{array}{c}2 \text { nd } \\
\text { ratoon }\end{array}$ & $\begin{array}{l}\text { Plant } \\
\text { cane }\end{array}$ & $\begin{array}{c}1 \text { st } \\
\text { ratoon }\end{array}$ & $\begin{array}{c}2 \text { nd } \\
\text { ratoon }\end{array}$ & $\begin{array}{l}\text { Plant } \\
\text { cane }\end{array}$ & $\begin{array}{c}1 \text { st } \\
\text { ratoon }\end{array}$ & $\begin{array}{l}2 \text { nd } \\
\text { ratoon }\end{array}$ \\
\hline GT 54-9 & $6.67 \mathrm{ab}$ & $16.67 \mathrm{a}$ & $25.00 \mathrm{a}$ & $2.08 \mathrm{a}$ & $5.00 \mathrm{a}$ & $12.92 \mathrm{a}$ & $1.00 \mathrm{~b}$ & $1.67 \mathrm{~b}$ & $3.00 \mathrm{c}$ \\
\hline G84-47 & $3.33 \mathrm{bc}$ & $6.67 \mathrm{~cd}$ & $16.67 \mathrm{~b}$ & $0.42 \mathrm{c}$ & $0.83 \mathrm{~b}$ & $1.25 \mathrm{~d}$ & $0.00 \mathrm{c}$ & $0.00 \mathrm{~d}$ & $0.00 \mathrm{e}$ \\
\hline G 2006-6 & $1.67 \mathrm{c}$ & $5.00 \mathrm{~d}$ & $6.67 \mathrm{de}$ & $0.83 \mathrm{bc}$ & $1.25 \mathrm{~b}$ & $1.25 \mathrm{~d}$ & $0.67 \mathrm{~b}$ & $1.00 \mathrm{c}$ & $1.67 \mathrm{~d}$ \\
\hline G 2010-7 & $3.33 \mathrm{bc}$ & $5.00 \mathrm{~d}$ & $10.0 \mathrm{~cd}$ & $1.67 \mathrm{ab}$ & $2.08 \mathrm{~b}$ & $5.83 \mathrm{~b}$ & $0.00 \mathrm{c}$ & $0.00 \mathrm{~d}$ & $0.00 \mathrm{e}$ \\
\hline G 2010-26 & $3.33 \mathrm{bc}$ & $3.33 \mathrm{~d}$ & $5.00 \mathrm{e}$ & $0.42 \mathrm{c}$ & $0.83 \mathrm{~b}$ & $1.25 \mathrm{~d}$ & $0.00 \mathrm{c}$ & $0.00 \mathrm{~d}$ & $0.00 \mathrm{e}$ \\
\hline G 2011-13 & $5.0 \mathrm{abc}$ & $11.67 \mathrm{~b}$ & $21.67 \mathrm{a}$ & $0.83 \mathrm{bc}$ & $1.25 \mathrm{~b}$ & $2.92 \mathrm{c}$ & $0.67 \mathrm{~b}$ & $1.67 \mathrm{~b}$ & $4.33 \mathrm{~b}$ \\
\hline G 2011-74 & $1.67 \mathrm{c}$ & $3.33 \mathrm{~d}$ & $5.00 \mathrm{e}$ & $0.83 \mathrm{bc}$ & $1.25 \mathrm{~b}$ & $1.67 \mathrm{~cd}$ & $0.00 \mathrm{c}$ & $0.00 \mathrm{~d}$ & $0.00 \mathrm{e}$ \\
\hline G 2011-79 & $3.33 \mathrm{bc}$ & $6.67 \mathrm{~cd}$ & 8.33 cde & $0.83 \mathrm{bc}$ & $1.67 \mathrm{~b}$ & $2.08 \mathrm{~cd}$ & $0.00 \mathrm{c}$ & $0.00 \mathrm{~d}$ & $0.00 \mathrm{e}$ \\
\hline G 2011-82 & $8.33 \mathrm{a}$ & $10.0 \mathrm{bc}$ & $11.67 \mathrm{c}$ & $1.25 \mathrm{abc}$ & $5.42 \mathrm{a}$ & $6.25 \mathrm{~b}$ & $0.00 \mathrm{c}$ & $0.00 \mathrm{~d}$ & $0.00 \mathrm{e}$ \\
\hline G 2012-50 & $5.00 \mathrm{abc}$ & $6.67 \mathrm{~cd}$ & $6.67 \mathrm{de}$ & $1.25 \mathrm{abc}$ & $1.25 \mathrm{~b}$ & $1.67 \mathrm{~cd}$ & $2.33 \mathrm{a}$ & $3.67 \mathrm{a}$ & $5.00 \mathrm{a}$ \\
\hline
\end{tabular}

Means followed by same letter within each column are not significantly different at 0.05 level of probability

5.1.2. Susceptibility of sugarcane promising genotypes to infection with smut disease under natural conditions:

Data in Table (5) indicated that, the tested genotypes significantly differed in response to natural infection with smut disease in the three tested seasons. Only, four genotypes out of eleven showed symptoms of the smut disease which were GT 54-9, G 2006-6, G 2011-13 and G 2012-50 in the three tested seasons. The highest disease infection values $(2.33,3.67$ and $5.00 \%)$ were recorded by $\mathrm{G}$ 2012-50genotype in plant cane, first and second ratoon seasons, respectively. G 47-84, G 2010-7, G 2010-26, G 2011-74, G 2011-79 and G 2011-82 genotypes had zero infection with smut disease during the three tested seasons and apparently healthy to smut infection. The resistance to smut may be due to the physical properties of bud structure which precludes infection under natural conditions, and not any chemical substance in the composition of the plant (Fawcett, 1946 and Mehareb et al., 2018). On the other hand, the differences in susceptibility of sugarcane genotypes to smut disease may be due to buds tightly enclosed within scale leaves can escape infection buds or chemical properties rather than on bud morphology. (Amrote, 2014 and Mehareb et al., 2018).

\subsection{Viral diseases:}

5.2.1. Susceptibility of sugarcane promising genotypes to infection with streak disease under natural conditions:

Data in Table (6) illustrated that, there were only the four tested genotypes significantly affected by the natural infection with streak disease in all tested seasons. It could be arranged the infected genotypes with such diseases in the following descending order according to infection\%: G 20066>G 2010-26>G 2011-74>G 2011-79.

Table 6: Susceptibility of certain sugarcane promising genotypes to infection with streak and mosaic diseases under natural conditions in the tested seasons 2015/16 (plant cane) 2016/17 (first ratoon) and 2017/18 (second ratoon)

\begin{tabular}{|c|c|c|c|c|c|c|}
\hline \multirow{3}{*}{ Genotypes } & \multicolumn{3}{|c|}{ Streak disease } & \multicolumn{3}{|c|}{ Mosaic disease } \\
\hline & \multicolumn{3}{|c|}{ Infection percentage } & \multicolumn{3}{|c|}{ Infection percentage } \\
\hline & Plant cane & 1st ratoon & 2nd ratoon & Plant cane & 1st ratoon & 2nd ratoon \\
\hline G.T. 54-9 & $0.00 \mathrm{c}$ & $0.00 \mathrm{c}$ & $0.00 \mathrm{~d}$ & $0.67 \mathrm{a}$ & $1.00 \mathrm{a}$ & $2.00 \mathrm{a}$ \\
\hline G 84-47 & $0.00 \mathrm{c}$ & $0.00 \mathrm{c}$ & $0.00 \mathrm{~d}$ & $0.00 \mathrm{~b}$ & $0.00 \mathrm{~b}$ & $0.00 \mathrm{~b}$ \\
\hline G 2006-6 & $76.67 \mathrm{a}$ & $80.00 \mathrm{a}$ & $95.00 \mathrm{a}$ & $0.00 \mathrm{~b}$ & $0.00 \mathrm{~b}$ & $0.00 \mathrm{~b}$ \\
\hline G 2010-7 & $0.00 \mathrm{c}$ & $0.00 \mathrm{c}$ & $0.00 \mathrm{~d}$ & $0.00 \mathrm{~b}$ & $0.00 \mathrm{~b}$ & $0.00 \mathrm{~b}$ \\
\hline G 2010-26 & $76.67 \mathrm{a}$ & $78.33 \mathrm{a}$ & $83.33 \mathrm{~b}$ & $0.00 \mathrm{~b}$ & $0.00 \mathrm{~b}$ & $0.00 \mathrm{~b}$ \\
\hline G 2011-13 & $0.00 \mathrm{c}$ & $0.00 \mathrm{c}$ & $0.00 \mathrm{~d}$ & $0.00 \mathrm{~b}$ & $0.00 \mathrm{~b}$ & $0.00 \mathrm{~b}$ \\
\hline G 2011-74 & $13.33 \mathrm{~b}$ & $18.67 \mathrm{~b}$ & $48.33 \mathrm{c}$ & $0.00 \mathrm{~b}$ & $0.00 \mathrm{~b}$ & $0.00 \mathrm{~b}$ \\
\hline G 2011-79 & $0.67 \mathrm{c}$ & $1.00 \mathrm{c}$ & $2.00 \mathrm{~d}$ & $0.00 \mathrm{~b}$ & $0.00 \mathrm{~b}$ & $0.00 \mathrm{~b}$ \\
\hline G 2011-82 & $0.00 \mathrm{c}$ & $0.00 \mathrm{c}$ & $0.00 \mathrm{~d}$ & $0.00 \mathrm{~b}$ & $0.00 \mathrm{~b}$ & $0.00 \mathrm{~b}$ \\
\hline G 2012-50 & $0.00 \mathrm{c}$ & $0.00 \mathrm{c}$ & $0.00 \mathrm{~d}$ & $0.00 \mathrm{~b}$ & $0.00 \mathrm{~b}$ & $0.00 \mathrm{~b}$ \\
\hline
\end{tabular}

Means followed by same letter within each column are not significantly different at 0.05 level of probability 
This infected $\%$ of such disease tended to increase as seasons advanced in times. Six genotypes, GT 54-9, G 84-47, G 2010-7, G 2011-13, G 2011-82 and $G$ 2012-50had zero infection and apparently free to streak infection in all tested seasons. Diversities among sugarcane genotypes to streak virus disease may be due to their variations in genetic constitution (El-Sogheir and Abd El-Fattah, 2009 and Mehareb et al., 2018).

5.2.2. Susceptibility of sugarcane promising genotypes to infection with mosaic disease under natural conditions

Data in Table (6) demonstrated that nine genotypes were free infection and apparently free of mosaic infection in the three tested seasons. Merely, check genotype GT 54-9 was the only one which affected by mosaic disease infection. The infected percentages were $0.67,1.00$ and $2.00 \%$ in the plant cane, first and second ratoon seasons, respectively. Possibly, response of plant to virus infection indicated by the absence of some biochemical changes such as defense-related enzymes, carbohydrate accumulation, or photosynthetic and photo-assimilation activity (Yang et al., 2007 and Mehareb et al., 2018). Peroxidase is an enzyme in plants that occurs in response to some stimuli such as pathogen infection, chemical agents, or mechanical agents. Passardi et al., 2004, Rani and Jyothsna 2010 and Mehareb et al., 2018who suggested that an increase in peroxidase activity is correlated with the degree of defense of the host plant, which involves lignin biosynthesis and cell wall reinforcement. El-Sogheir and Abd El-Fattah, 2009 and Mehareb et al., 2018 revealed that variations among sugarcane genotypes to virus diseases may be due to their differences in genetic constitution.

\section{CONCLUSION}

The effects on traits were estimated when they had the same effects during the three tested seasons. In comparison among sugarcane traits, it could be concluded that GT 54-9 had the highest stalk length, stalk weight, sucrose $\%$, purity $\%$ and all tested productivity traits. G 84-47 owned the highest brix $\%$, sucrose $\%$ and cane yield. However, the highest brix\% was recorded to $G$ 2006-6. The lowest values of stalk length, sugar yield and stalk weight were scrutinized to G 2010-26, G2011-74 and $\mathrm{G}$ 2011-79, respectively. In addition, the lowest stalk diameter and highest of tillering were observed to $\mathrm{G}$ 2011-13. Also, the lowest tested qualitative traits, sugar recovery $\%$ and yield were recorded to G 2012-50. G 2010-7 and G 2011-82 showed no distinct behavior for all traits. Regard to infection with the four tested diseases, the highest infection with pokkah boeng, smut and mosaic diseases were observed on GT 54-9. Such genotype showed no infection by streak disease. G84-47 had the lowest $\mathrm{DS} \%$ for pokkah boeng disease and uninfected by smut and the two tested virus diseases. G 2006-6 gained the lowest infection by pokkah boeng and smut, the highest infected by streak disease and didn't infect by mosaic disease. G 2010-26free of infection by smut and mosaic diseases and highly infected by streak disease. On the other hand, G 2011-74 had low infection by pokkah boeng and no infection by smut and the two tested virus diseases. G 2011-79 had the same behavior as the previous genotype but showed the least infection by pokkah boeng and streak diseases and uninfected by the two tested virus diseases. Also, G 2011-13 and G 201250 were the highest infected by smut and uninfected by the two tested virus diseases. Both ofG 2010-7 and G 2011-82uninfected by smut and the two tested virus diseases.

\section{REFERENCES}

Abo Elenen F.F.M., E.M. Mehareb, M.A. Ghonema and A. El-Bakry (2018). Selection in sugarcane germplasm under the Egyptian conditions. Open Access J. of Agri. Res., 3(3): 1-13.

AOAC (1995). Official Methods of Analysis.Association of Official Analytical Chemists. Washington, D.C., USA. 642.

Agrios G.N. (2005). Plant Pathology ( $\left.5^{\text {th }} \mathrm{ed}\right)$. Harcourt Academic Press, New York. 687pp.

Amrote T.W. (2014). Integrated management of sugarcane smut (Ustilagoscitaminea) through hot water treatment and fungicides at WongiShoa sugar estate.M.SC.Thesis, College of Agri. and Environ.Sci.Haramaya Univ., 63pp.

Burner D. and M. Grisham (1993). Resistance of sugarcane relatives injected with Ustilagoscitaminea.Plant Disease, 77: 12211223.

Khan I.A., S. Bibi, S. Yasmin, A. Khatri and N. Seema (2012). Correlation studies of agronomic traits for higher sugar yield in sugarcane. Pak. J. Bot., 44: 969-971.

Costatsoftware (1988). Microcomputer program analysis.Co-HortSlturaloftware, Berkely, CA, USA.

Cuenya M.I., E.R. Chavanne, S. Ostengo, M.B. Garcia, M. Ahmed, D.D. Costilla, R.C. Diaz, M.A. Espinosa, N. Delgado and J.V. Diaz (2011). Productive and phytosanitary TUC 9510 , a new sugarcane cultivar produced by the EEAOC. Advance Agro industrial, 32 (4): 1421.

Duttamajumder S. K. (2004). Bacterial diseases of sugarcane in India: a bird's eye view. In: Sugarcane pathology: bacterial and nematodes diseases, Rao GP, Saumtally AS, Rott P, (eds). Science Publishers: 15-50.

El-Sogheir K.S. and A.I. Abd El- Fattah (2009). Evaluation of some promising sugarcane varieties under different row spacing.J.Biol. Chem. \& Environ Sci., 4(1): 285-318. 
Fauconnier R. (1993). The Tropical Agriculturist: Sugar Cane. $3^{\text {rd }}$ ed.Published by Macmillan Press Ltd, London and Basingstoke.

Fawcett G.L. (1946). Department to de BotanicaFitopathology. Ex Memoria annual delano 1945. Rev. Ind. Agric. Tucuman 36 (159): 165- 166. (R. A. M. 28: 54-55).

Grisham M.P. (2000). Mosaic. In: A guide to sugarcane diseases (edsRott P, Comstock JC, Croft BJ and Saumtally A.S. CIRAD/ISSCT, Montpellier.

Grisham M.P. and Y. B. Pan (2007). A genetic shift in the virus strains that cause mosaic in Louisiana sugarcane. Plant Dis. 91:453-458.

Jose R., B. Louis, S. Goyari,S.Waikhom, P. HandiqueandN.Talukdar (2016). Biotrophic interaction of Sporisoriumscitamineumon a new host -Saccharumspontaneum. Micron, 81: 815 .

Lemma A., H.Hagos,Y. Zekarias and A. Tekle (2015). Study on the reaction of sugarcane genotypes (CIRAD-2011) to sugarcane smut (Sporisoriumscitamineum) in the Ethiopian sugarcane plantations. Adv Crop Sci. and Tech., 3: 181.

Martinez M., I. Medina,S. Naranjo, C.W. Rodriguez,R.de.Armas, D. Pinon, C. Vicente and M.E. Legaz (2000). Changes of some chemical parameters, involved in sucrose recovery from sugarcane juices, related to the susceptibility or resistance of sugarcane plants to smut (Ustilagoscitaminea). Inter. Sugar J., 102: 445-448.

Mehareb E.M., S.F. Abou-Elwafa and M.O.A. Galal (2015).Comparative performance of sugarcane genotypes for ratoonability in early clonal selection stages. J. Sugarcane Res., 5 (2): 11 21.

Mehareb E.M. and M.O.A. Galal (2017). Ratooning ability of some promising Egyptian sugarcane varieties. In. J. Sugarcane Tech.,32(02): 50-59.

Mehareb E.M., K. Yang, J. Zhao, Fouz F.AboElenen, Q.Wei, F. Zhan, J. Liu, H. Xia, L. Yao, P. Zhao, Y. Zhao and C. Wu(2017). Evaluation of seventy six sugarcane families at early selection stages. J. Pl. Breed.\& Crop Sci., 9(9): 151-159.

Mehareb E.M., M.A.M. Osman and A.M. Fahmy (2018). Screening sugar cane genotypes for the lesser sugar cane borer, chiloagamenonbels and four main diseases resistance in Egypt. Egypt. J. Plant Breed, 22 (4): 659 - 683.

Osman M.A.M.; M.A.E. Hassan, M.M.A. El-Kholi and A.A. Elneshar (2014). Studies on pokkahboeng disease of sugarcane. PhD. SC. Thesis, Faculty of Agri., Assiut Univ., Assiut, Egypt, 195 pp.

Passardi F., C. Penel and C. Dunand (2004). Performing the paradoxical: How plant peroxidases modify the cell wall. Trends Plant Sci.,9: 534-540.
Piepenbring M.,M. Stoll and F. Oberwinkler (2002).The generic position of Ustilagomaydis, Ustilagoscitaminea and Ustilagoesculenta (Ustilaginales). Mycological Progress, 1: 7180.

Ramirez E. and H. Nass (2005). Status pokkahboeng (Fusariummoniliforme) in Yaracuy Yaritagua in the years 2003 to 2005. VICongresoNacional Sugar atavistic.(Memoirs CD rom version).

Rani P.U. and Y. Jyothsna (2010). Biochemical and enzymatic changes in rice as a mechanism of defense.ActaPhy. P1., 32: 695-701.

Rott P., A. Bailey, J.C. Comstock, B.J. Croft and A.S.Sauntally (2000). A guide to sugarcane diseases.Published by CIRAD and ISSCT.339 pp.

Sharma, P.D. (2006). Plant Pathology. Alpha Science International Ltd. Oxford, U.K.

Singh A., P.K. Bhatnagar, A.Q. Khan and P.K. Shrotria (2003). Association of quality character with cane and commercial cane sugar yields in sugarcane. Sugar Tech., 5: 197-198.

Steel R.G.D. and J.H. Torrie (1981). Principles and procedures of statistic.A biometricalapproach. $2^{\text {nd }}$ Ed. McGraw.Hill Kogahusha Ltd. pp. 633.

Sundar A.R.,E.L. Barnabas, P. Malathi and R. Viswanathan (2012). A mini-review on smut disease of sugarcane caused by Sporisoriumscitamineum.In Botany In. Tech, pp. 107-128.Ed. J.K. Mworia. Rijeka, Croatia: In. Tech.

Tahir M, I.H. Khalil, P.H. McCord and B. Glaz (2014). Character association and selection indices in sugarcane. Amer. J. Exp. Agri., 4: 336.

Tokeshi H. (2005). Doencas de cana-de-acucar (hybridos de Saccharumspp.). In Manual de Fitopatologia: doenças das plantascultivadas. $4^{\text {th }}$ ed, pp.: 207-225.

Vishwakarma S.K.; P. Kumar; A. Nigam, A. Singh and A. Kumar (2013). Pokkahboeng: An emerging disease of sugarcane. J. P1. Path. Micro., 4: $\quad 170 . \quad$ doi: $10.4172 / 2157$ 7471.1000170

Whittle, P. J. and L. Irawan (2000). Pokkahboeng: A Guide to Sugarcane Diseases. Rott P, Bailey RA, Comstock JC, Croft BJ, Saumtally AS, (eds.). CIRAD/ISSCT, Montpellier: 136-140.

Yadav R.L. and R.K. Sharma (1980). Effect of nitrogen levels and harvesting dates on quality traits and yield of four sugar cane genotypes. Indian J. Agric. Sci., 50: 581-589.

Yang C., R. Guo, F. Jie, D. Nettleton, J. Peng, T. Carr, J.M. Yeakley, J.B. Fan and Whitham (2007). Spatial analysis of Arabidopsis thaliana gene expression in response to turnip mosaic virus infection. Mol. Plant Microbe Interact. 20: 359-370. 


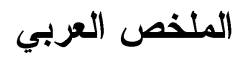

\section{تقييم الانتاجية والجودة و النمو والاصابات المرضية لبعض التر اكيب الوراثية المبشرة}

\author{
'محمد عبدالغنى محمد عثمان'، العربى سالم رمضان سالم"

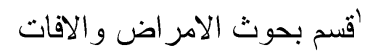 \\ أقسم بحوث الفيسيولوجى و الكيمياء \\ معهد بحوث المحاصيل السكرية، مركز البحوث الزر اعية - الجيزة- مصر
}

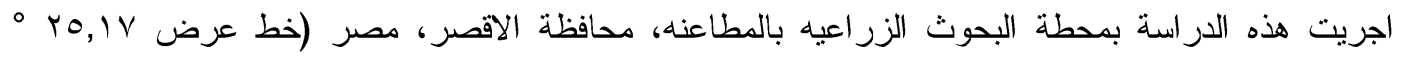

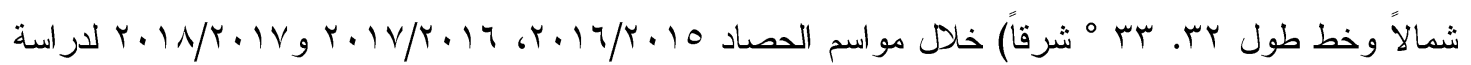
الصفات الانتاجية و الجود و النمو و العدوى الطيبعيه لعشرة من التر اكيب الور اثثة لمحصول قصب السكر متضمنة الصنفالتجارى GT 54-9 كصنف مقارنه. حيث زرعت التراكيب الور اثيه في ثلاث مكررات فى تصميم قطاعات كاملة العشو ائيه.

\section{و يمكن تلخيص نتائج هذا الارسة على النحو التالي:}

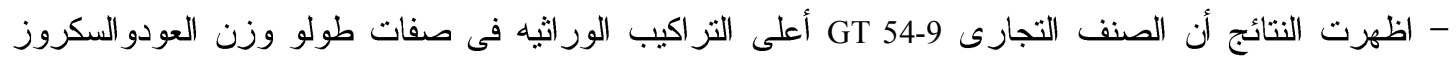

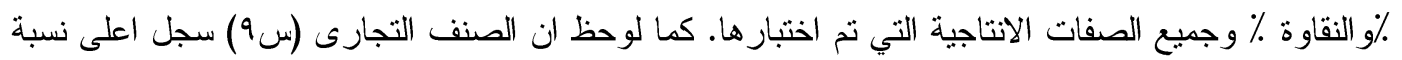

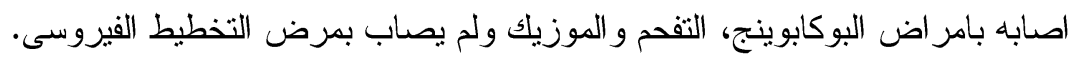
- سجل الصنف 84-47 أعلى نسبه مئويه فى صفتى البركس، السكروز وحاصل العيدان وسجل شدة اصابه منخفضه بمرض البو كابوينج ولم يصاب بمرض التفحم و الامر اض الفئ الفيروسيه المختبره.

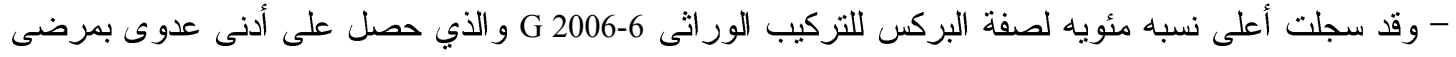

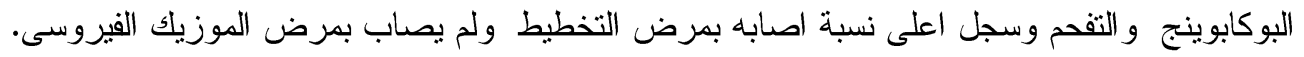

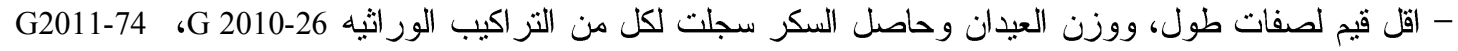
و G 2011-79 على الترتيب. وفيما ينعلق بمرض التخطيط فان اعلى نسبة مئوية للاصابه سجلت على التركيب

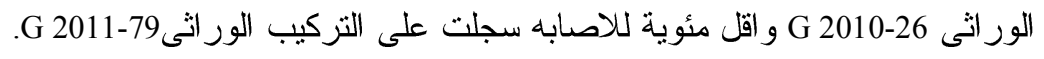

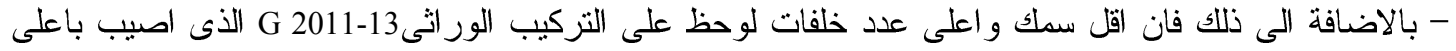
نسبه مئويه للاصابه بمرض التفحم ولم بصاب بالامر اض الفيروسيه التخطيط والموزيك. ايضا القل نسبة مئويه

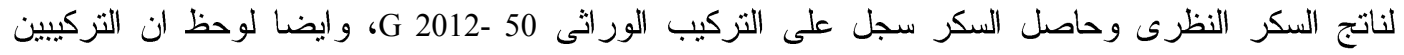

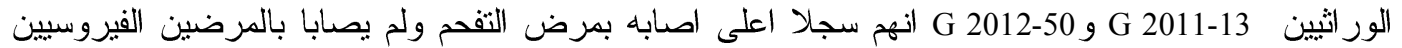
المختبرين. 
- التركييين الور اثثين-2010 G و G 2012-82 لم تظهر أي سلوك و اضح لجميع الصفات ولم بصابو ا بامر اض التفحم ومرضى التخطيط و الموزيك.

- تحت ظروف هذا البحث بمكن التوصيه بان الصنف التجارى GT 54-9 مناسب للزر اعه بالحقول و المناطق الملوثة بمرض التخطيط ليعطى اعلى وزن للعيدان و اعلى حاصل قصب وسكر بينما التركيب الور اثى 47-84 مناسب للزر اعه بالحقول و المناطق التى الملوثة بمرض التفحم ومرضى التخطيط والموزيك ليعطى اعلى محصول قصب. - التر اكيب الور اثيه الاخرى اختلفت من موسم لاخر وسجلت استجابات مختلفه للامرض المختبره. 